\title{
FEEDBACK CONTROL SYSTEM WITH AN ADDITIVE DISTURBANCE IN THE CONTEXT OF BIOLOGICAL SCIENCES
}

\author{
Ricardo Alves Martins*, Marcio Eisencraft*, Luiz Henrique Alves Monteiro ${ }^{\dagger}$, José \\ Guilherme Chaui-BerlincK ${ }^{\ddagger}$ \\ * Escola Politécnica, Universidade de São Paulo \\ São Paulo, SP, Brasil \\ ${ }^{\dagger}$ Escola de Engenharia, Universidade Presbiteriana Mackenzie e Escola Politécnica, Universidade de São Paulo \\ São Paulo, SP, Brasil \\ ${ }^{\ddagger}$ Instituto de Biociências, Universidade de São Paulo \\ São Paulo, SP, Brasil
}

Emails: ricardom@usp.br, marcio@lcs.poli.usp.br, luizm@mackenzie.br, luizm@usp.br, jgcb@usp.br

\begin{abstract}
Resumo - Nos cursos introdutórios de Engenharia, a análise de sistemas de controle em malha fechada com perturbação aditiva geralmente envolve dispositivos eletromecânicos. Tais sistemas de controle merecem ser estudados pela sua própria importância, mas o significado dessa análise pode-se enfatizada, por meio de alguns exemplos fora dos domíniosda Engenharia pura. Nesse artigo, propoe-se um modelo simplificado do sistema termorregulador de aves e mamíferos que é responsável pelo controle de temperatura, de modo a mostrar como os conceitos-chave de sistemas em malha fechada podem emergir em um contexto diferente. As nossas expectativas são melhorar e dar caminhos alternativos para o estudo deste tipo de sistemas de controle.
\end{abstract}

\begin{abstract}
In introductory engineering courses, the analysis of closed-loop control systems with additive disturbance usually involves electromechanical devices. Such control systems deserve to be studied by their own merits, but the significance of this analysis might be highlighted by means of some examples outside the pure engineer domains. Here we propose a simplified model of the avian/mammalian thermoregulatory system responsible for temperature control in order to show how the key concepts of closed-loop systems could emerge in a different context. Our expectations are to improve and to give alternative paths for the study of this type of control systems.
\end{abstract}

Keywords- Dynamical Systems Applications, Thermoregulatory Model, Disturbance Analysis, Closed-loop Control Systems

\section{Introduction}

In introductory courses on classical control theory, students learn that closed-loop systems are less sensitive to perturbation than the corresponding open-loop ones. Such a conclusion is usually drawn by analyzing, for instance, a feedback control system with an additive disturbance, as shown in Fig. 1 (e.g. (Dutton et al., 1997; Franklin et al., 2005; de Klerk and Craig, 2004; Kuperman and Rabinovici, 2005)). In such a scheme, the controlled variable $C(s)$ of the process is measured by the sensor $H(s)$ and compared with the reference $R(s)$. The difference $R(s)-H(s) C(s)$, called system error $E(s)$, feeds the compensator $G(s)$, and the compensator output is the signal actuating on the process. The steady-state error is affected by $R(s)$ and by the external disturbance $D(s)$ added to the process output.

In undergraduate engineering classes, the block diagram shown in Figure 1 usually involves electromechanical devices, like satellite attitude control systems (e.g. (Franklin et al., 2005)) or electric motors (e.g. (Kuperman and Rabinovici, 2005)). In order to enrich the presentation of possible systems of this type in a different context, here we derive it for a simplified model of the

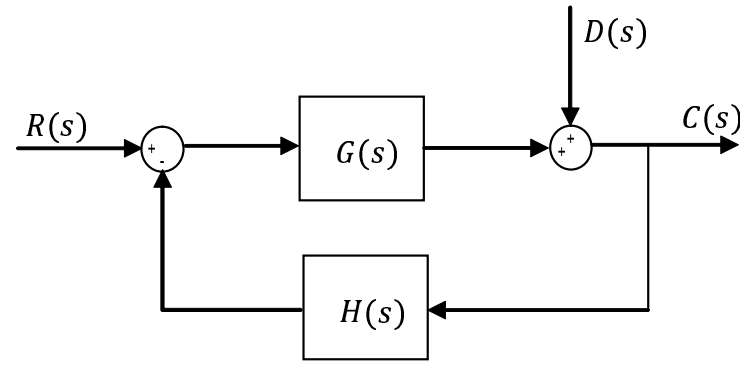

Figure 1: The block diagram represents a generalized feedback control system with additive disturbance $D(s)$. The controlled variable $C(s)$ of the process is required to track the reference input $R(s)$. The tracking error $E(s)=R(s)-H(s) C(s)$ is the input to the plant.

thermoregulatory system responsible for temperature control in birds and mammals. Even though we focus in some aspects of a biological temperature control system, there is a vast area of different purposes related to this matter. For instance, the design of temperature control systems is obviously important in industrial applications (e.g. (de Miranda Montenegro et al., 2006; Salau et al., 2005)).

Our biological model follows from Newton's law of cooling, which states that the rate of en- 
ergy exchange due to heat transfer of a body is proportional to the difference between body temperature and surrounding (ambient) temperature. It incorporates the physiological feature of those animals that, in their majority, rely on metabolic energy conversion for the maintenance (regulation) of a somewhat limited range of body temperature throughout the day. These two features, i.e., metabolic energy conversion for thermoregulation and a limited range of body temperature, are named endothermy and homeothermy, respectively.

The proposed thermoregulatory model is described in Section 2 and its behavior is analytically determined in Section 3. In Section 4, the main conclusions are presented.

\section{A Thermoregulatory Model}

A very basic fact about body temperature is that it represents, at any given time $t$, a balance between the amount of energy received or produced by an animal and the energy lost to the surroundings, either actively or passively.

In the case of endothermic animals, body temperature $T_{b}(t)$ is actively regulated by the control of both energy production - by shivering and nonshivering thermogenesis - and energy loss - by mechanisms of thermal exchange, as changes in posture, peripheral blood perfusion and evaporative water loss. Notice that we will not discuss $T_{b}$ long-term regulation related to changes in fur or feathers, dermal fat thickness etc. Also, body temperature control in mammals resides, mainly, in hypothalamic centers, while in birds there are other peripheral controllers; therefore, we will refer simply to a "temperature controller" in a general sense in the text.

In this way, for an endotherm to maintain a constant body temperature (homeothermy), energy production must equal energy loss by heat. Without loss of generality in the present context, we will assume that $T_{b}(t)$ is homogeneous throughout the organism. Then, a simple model of body temperature variation would be given as the difference between $T_{b}(t)$ and environmental temperature $T_{a}(t)$ generating an energy loss to the surroundings proportional to the thermal conductance $^{1} \chi\left(\mathrm{J}^{o} \mathrm{C} \mathrm{s}^{-1}\right)$; the difference between such a loss and the energy input represented by the metabolic rate $M\left(\mathrm{~J} \mathrm{~s}^{-1}\right)$ results in a $T_{b}(t)$ $\left({ }^{\circ} \mathrm{C}\right)$ variation inversely proportional to the product of body mass $B(\mathrm{~g})$ and the mean specific heat of tissues $C\left(\mathrm{~J} \mathrm{~g} \mathrm{~g}^{-1 o} \mathrm{C}^{-1}\right)$ (Cooper, 2002; ChauiBerlinck et al., 2005). Mathematically we could 
domain:

$$
T_{b}(s)=(-h
$$


By considering null initial conditions and applying the anti-Laplace transform, this expression becomes:

$$
B C \ddot{T}_{b}(t)+\chi \dot{T}_{b}(t)+K h T_{b}(t)=K h T_{s}+\chi \dot{T}_{a}(t)
$$

where the dot means derivative with respect to the time.

In steady-state of $T_{b}$, i.e., when $\dot{T}_{b}(t)=0$ and $\ddot{T}_{b}(t)=0$, we have:

$$
T_{b}(t)=T_{s}+\underline{\chi}
$$

